GRZEGORZ SZPILA

Jagiellonian University, Cracow

\title{
LITERARY PAREMIC LOCI IN SALMAN RUSHDIE'S NOVELS
}

Keywords: proverbs, paremiostylistics, paremic loci, novels, Salman Rushdie

\begin{abstract}
The paper deals with the identification of proverbs in a literary text, which is believed to be the initial stage in the analysis of paremias in literary context and part and parcel of any paremiostylitic analysis. Proverbs manifest themselves in what the author calls a paremic locus. Paremias are present in a text on the formal level, where a particular proverb is signalled by its structure, either canonical or modified. Proverbs can be identified as well on the semantic plane, although in this case their presence is impossible to ascertain in objective terms. The author analyses the ten novels by Salman Rushdie, which all provide ample evidence of paremic loci.
\end{abstract}

An analysis of paremias in any written or spoken material must involve the stage of proverb identification. In fact, the identification of proverbs is a sina qua non for further analysis to take place. It is the initial requirement for any kind of paremic investigation, equally so for paremiostylistics, which I use to refer to an analysis of proverbs in literary texts (Szpila 2007, 2008a). ${ }^{1}$ Only after all the proverbs have been registered, that is identified, can the next steps be taken by paremiologists and paremiostylisticians. We may of course wonder if there is an earlier stage in the analysis of proverbs in a literary text for example and indeed we could say perhaps that the process of identification may be eased as well as influenced by the specific characteristics of a literary genre, an author and his literary output as such. All such literary characteristics may make an analyst more sensitive to the paremiological or paremiostylistic character of the text he is studying. The list of proverbs established

1 In its broader sense paremiostylistics is an investigation of proverbs in all kinds of discourse. 
for a particular text, a fragment of a text or indeed a collection of texts (by the same writer, for instance) is a result of what I call a paremic or phraseological reading of text, that is such reading which focuses on the identification and interpretation of all the potential phraseological and paremiological loci therein (cf. Szpila 2009a). In fact, only such a list provides the ultimate evidence of the phraseological / paremic character of the material studied. On the other hand, however, the overall metaphorical character of a text, which may be to a lesser or greater extent due to phraseological metaphors, can easily make the identification of proverbs a more difficult process as some seemingly paremic metaphors can simply not be meant to be proverbial at all and should perchance be treated as novel metaphors instead.

In this article I would like to focus exclusively on the process of the identification of proverbs in literature, with the novels by Salman Rushdie serving as illustrations. Rushdie's books are extremely useful as they provide not an inconsiderable number of examples of paremic as well as phraseological loci. I consider Rushdie to be a phraseological writer as he makes use of many a phraseological unit, which represent all possible phraseological categories, as well as many proverbs (my corpus comprises over 100 proverbs - paremic types - and over 200 actualizations - paremic tokens - in all his ten novels so far). ${ }^{2}$

To start with I would like to define a paremic locus, whose identification I would like to address in the subsequent paragraphs. A paremic locus is a narrative space (any text space) which can be matched with a proverb. A paremic locus is not necessarily to be associated with a proverb's form: a paremic locus can be a proverb in its canonical form, which is the prototypical paremic locus, but it may be any stretch of text which delineates the boundaries of a proverb's presence and manifestation. Neither is the paremic locus to be identified as a narrative space which is within a proverb's referential scope. A paremic locus is where we see a signal, either semantic or formal or both, of a proverb, which then is analysed as applying to various elements of the text, so it is a question of the proverbs' function with reference to a novel's plot and its interpretable semantics. This physical anchoring of a proverb may be then scrutinized against the semantics of the text and described in terms of the proverb's micro- and macrofunctions as well as hyper- and metafunctions (cf. Szpila 2009b).

As paremic loci are not necessarily proverbs in their canonical forms, not all of them can be identified without difficulty. It may happen of course that an analysed text comprises proverbs in their unmodified standard - canonical - forms and no other proverbs are found in less obvious paremic loci. Rushdie's novels do not fall into this category and therefore they are a valuable source of information concerning the ways in which proverbs may manifest their presence in literary texts. As might be expected, examples of paremic loci which can be matched with proverbs are found in his novels, for example: Easier said than done (SV 401), Patience is a virtue (H97),

2 A detailed analysis of the forms and functions of proverbs in Salman Rushdie's novels can be found in Szpila (2008a). 
Every cloud has a silver lining (MC 425), If the cap fits, wear it (G 179), Practice makes perfect ( $G$ 166). These proverbs are used in the respective novels in their unaltered forms. It may happen of course that within one literary corpus (all Rushdie's novels, for example), a proverb is used in more ways than one and its manifestations need to be described and classified differently. It is interesting to note at this point that in the analysed corpus about $70 \%$ of the proverbs are modified and only $30 \%$ are used by the novelist in their unaltered forms (cf. Szpila 2008a). So only the latter figure accounts for the most prototypical occurrences, with the remaining $70 \%$ manifesting their semantics through a variety of semantic and formal textual actualizations. When saying that a proverb is used prototypically in its unaltered form, I do not mean that this is how proverbs in general are used and that only in literature are they actualized differently. It would go against the intuitive as well as research-based observations to say that proverbs are not employed in innumerable ways in everyday communication, a fact which is reflected in literary texts. Obviously, literary language permits greater freedom in the creative manipulation of both the form and semantics of proverbs, but the differences are perhaps only in the quantity, not the quality of deployment.

On the strength of the above we can say that the identification of proverbs used in their unaltered forms is the easiest task of all and therefore I treat them here as prototypical uses as well as a starting point for any investigation. This applies as well to foreign proverbs which may be cited in their original form, for example: Noblesse oblige (MLS 333). If there is a likelihood of the proverb remaining unidentified the writer may resort to signalling the proverbial status of a structure via various textual markers of this genre. The most obvious is to simply name a locus proverbial by referring to the fixed expression in an appropriate way, by means of metatextual elements (cf., for instance, Barkema 1996: 145, Lüger 1996: 94), as in, for example, EF (169), the paremia The end justifies the means is called "a profound principle" and the proverb Never look a gift horse in the mouth in EF (269) is simply called a proverb. The quotational status of proverbs, their echoic status (Sperber and Wilson 1986: 238-239), is signalled in "He moves in mysterious ways: men say" (SV 95) or even by punctuation as in "I would like to say only this: that charity begins at home" (GBHF 134).

By the same token, the writer may refer to familiarity as a feature of all fixed expressions, for example: "Where there's a will, etc., I couldn't help thinking" (GBHF 189) and "don't look a gift horse andsoforth" (SV 39), with the markers of familiarity serving to activate the mental lexicon and steer our attention towards the stock of memorized items. Even in "Because a cat may look at a queen" (GBHF 385) the subordinator serves as a marker of familiarity as it refers to proverbs since a reservoir of familiar arguments.

These different references to the genre of proverb structure employed help to classify paremias easily even if a given proverb itself is not used in its canonical form(s) (cf. GBHF 385, EF 269). Indeed, it seems that by signalling their status among other expressions a writer is no longer interested in playing with their form and semantics, so the unmistaken evocation of the proverbs in the reader's mind 
comes to the fore. The function of such markers is to match a particular proverb with a particular text space.

Both canonical forms of proverbs and proverbiality markers of all types are not that frequent in the analysed novels. Consequently the identification of the remaining paremias may present various degrees of difficulty. The difficulty increases with the extent to which a given proverb in modified, that is when the canonical form has to be established, most importantly for the purpose of reference, through an intricate process of interpreting the modified form and matching it with its standard form. The difficulty is even greater when the semantics of a locus is not immediately apparent to the reader. Such cases cover all manner of textual operations on both the form and semantics of paremias, however, it is not my aim to analyse all of them. Let me just provide certain examples to illustrate my point: "WHERE THERE'S A WILL. The realization of his own power, of Virgil Jones' meaning, dawned on him" (G 72), "No accounting for tastes, that's all" (SV 7), "Nothing to it but organization; old Army habit, dies darn hard" (MC 311), "Love does not conquer all, except in the Bombay talkies; rip tear crunch will not be defeated by a mere ceremony; and optimism is a disease" (MC 444), "Violence was violence, murder was murder, two wrongs did not make a right: these are truths of which I was fully cognisant" (MLS 365), "Did you not see the everyday live-and-let-live miracles thronging its overcrowded streets?" (MLS 351). These examples show operations of subtraction, addition, as well as grammatical modifications and syntactic function shift. They are only a fraction of all the operations Rushdie uses to contextualize his proverbs (cf. Szpila 2008a). I would claim, however, that the identification of the corresponding proverbs is not significantly hindered. The subtraction of a proverb's elements, for example, is as frequent as the quoting proverbs in their complete forms and nowise is it difficult to establish a paremic locus (cf. Hewings, Hewings 2005: 96). However, we must not treat all alterations as insignificant in this respect as some may without doubt obscure the paremic picture. Paremic loci are occasionally marked by the significant lexical items of a proverb which serve as allusive devices (cf. Szpila 2008b). The allusive use of proverbs is a further strategy of proverb deployment, with the identification of the proverb alluded to is not difficult as the allusive loci contain characteristic elements of the proverbs. Identification is also necessary to interpret the intended meanings, cf. "Wasn't that a flying pig" (GBHF 293), "The old problem of ends and means" (F 227), "Pot and kettle, replied the voice. Mote and beam." (G 91), “Talk about pot and kettle,' he said. Question of mote and beam" (SV 278). These examples contain unmistaken reference to the respective proverbs and cannot be analysed without direct reference to them. Sometimes proverbial allusion may not be so obvious as the proverbial elements in question may be interpreted metaphorically without any reference to the semantics of the corresponding proverb. However, it is worth pondering to what extent the interpretation of such loci is determined by the reader's paremic knowledge and to what extent, on the other hand, we can construe the intended meaning without direct access to the proverb. And also, to what extent did Rushdie manipulate the proverb structure, did he simply apply the individual meanings to the elements without ever thinking of the proverb in question or did 
he intend to put the reader in mind of the proverb regardless of the ease with which the latter (reader) might interpret the fragment non-paremically?

The most interesting cases which have inspired me to focus on the recognition stage in a paremio-stylistic analysis are what I call, broadly speaking, and for lack of a better term, proverbial paraphrases. These are loci which semantically correspond to particular proverbs and function pragmatically as the latter, but which express the proverbial sense in totally different or alternative ways. The pragmatic context and the similarity to the proverbial images make us consider such loci as paremic in nature. Let us take the following as illustrative examples: "Mr Gibreel Farishta on the railway train to London was once again seized as who would not be by the fear that God had decided to punish him for his loss of faith by driving him insane" (SV 189) and "'God chooses many means', Ayesha rejoiced, 'many roads by which the doubtful may be brought into his certainty." (SV 240). To me the former example corresponds to Whom the gods would destroy they first make mad and the latter to God moves in mysterious ways (cf. SV 95). Probably, it is impossible to give a precise definition of a paremic paraphrase, or how similar or how different it should be from the corresponding proverb. Is, for example, the following: "the cover is not the best guide to the book" (SV 257) a paraphrase of You can't tell a book by its cover or not?

Sometimes, even a large stretch of narrative may feel to the reader as an extended version of a particular proverb. This could be illustrated by the following paragraph from The satanic verses (134), which could perhaps be matched with the proverb An Englishman's home is his castle:
Usually she was implacable in defence of her beloved fragment of the coast, and when summer weekenders strayed above the high tide line she descended upon them like a wolf on the fold, her phrase for it, to explain and to demand: - This is my garden, do you see. - And if they grew brazen, - getoutofitsillyoldmoo, itsthesoddingbeach, - she would return home to bring out a long green garden hose and turn it remorse- lessly upon their tartan blankets and plastic cricket bats and bottles of sun-tan lotion, she would smash their children's sandcastles and soak their liver-sausages, smiling sweetly all the while: You won't mind if I just water my lawn?

But it is probably pushing his luck on the reader's part to consider this as a paremic locus in which the proverb remains unspoken while the narrative begs to be summarized in the precious few words of the proverb. Such type of the semantic presence of a proverb is arguably the most elusive to prove, as the matching is a subjective operation on the part of the reader.

Yet another class of doubtful paremic loci is the following: proverbs that correspond to idioms which are treated as their allusions (Moon 1998: 29, 113) such as Forbidden fruit is sweet (GBHF 84, 129), It is the last straw that breaks the camel's back (GBHF 351), and The rotten apple injures its neighbours (SC 373). They are systemic allusions unlike novel textual ones and they can be omitted if we treat them as idioms only. In my approach to proverbs and idioms, however, I treat such fixed expressions as paremias but due to their unquestionable relationship to idioms I consider them as peripheral, as also they are infrequent. 
Last but not least, when identifying proverbs in a literary text such as a novel we may encounter apparently paremic loci but it is questionable which proverb they contain or refer to as there may be two or even more proverbs that can be matched with them. A case in point would undoubtedly be a contamination of two or more proverbs which may occur, however, to the best of my knowledge there is no example of paremic contamination in Rushdie's novels unlike idiomatic contamination which are found therein. I have found one example of a paremic locus which may illustrate this point, namely: "Once divided, always divided" (MLS 49). This paremic locus can be matched with $A$ house divided against itself cannot stand. This matching is made possible not only due to the similarity of the lexical content of the quote with the proverbial content but also due to the proverb being used in the novel three more times $(1,34,99)$, and where all of the actualizations are semantically co-referential with reference to the theme of the novel. The reference to the proverb is reinforced as if by one of the frequent proverbial structures: Once ... (sth), always ... (sth). The example then is a contamination of a concrete paremia and a paremic structure which carries the logico-semantic value of the proverbs which have this particular surface form. Moreover, not all expressions which share this or similar structures with established paremias can be legitimately defined as paremic loci. The justification should be sought in the semantics and functions they perform in the text vis à vis paremic senses and roles.

Apart from this type of contamination many paremic loci in Rushdie's novels have to be matched with the same or similar proverbial structural skeletons and the textually bound formations may be treated as either referring to a particular proverb or rather its formal syntactic schemata. For instance: "One betrayal often deserves another" (EF 292), "Once a scam man, always a ditto" (SV 262), "One boy's Paradise could be another fellow's Hell" (SV 203), "Surprise is the best policy" (SV 156) and "Murder breeds death" (MC 271). Here again we may be tempted to refer these loci to the proverbs One good turn deserves another, Once a thief, always a thief, One man's meat is another man's poison, Honesty is the best policy and Familiarity breeds contempt. Nevertheless, it remains out of the realm of possibility to decide if Rushdie uses these proverbs as structural templates only or has intended to play with their form and semantics. It has to be stated that the novel expressions do not modify the meanings of the quoted proverbs but they drink deep of the logical relations established by them which can be used to express other truths, however personal, subjective and situation-bound as they may be. I am tempted to treat such paremic locis as border line cases again occupying a position between the reference to particular proverbs on the one hand and the reflection of the polyfunctionality of some proverbial structures on the other.

And last and perhaps not least again, peripherally located are "new proverbs" or "pseudo-proverbs", original formulations of a principle, or truth aspiring to the status of paremia as being universally applicable. We can find such examples in Rushdie's novels and although such loci cannot be matched with any existing proverbs, we can say that they are proverbial in nature, viz. they are categorically matched with proverbs as a category of signs. A case in point might be: "Proper sowing 
ensures a good harvest" (S 153) or "A compulsory ocean sounds worse than a forbidden well" (SV 240).

I have essayed to highlight only a few ways in which proverbs can manifest themselves in a literary text and some problems which arise at the level of paremic recognition in texts. Although Rushdie's novels serve as good examples of paremic actualizations, due to the frequency of their occurrence as well as the multifaceted character of their actualization, this description cannot be treated as exhaustive. I hope I have managed to show yet again some of the difficulties which await a paremiostylistician at a very early stage of a paremic analysis of a literary text. Further studies of literature and proverbs deployed therein in all likelihood will reveal further problems as regards the recognition stage of paremic presences in literary texts as well as some ways of solving them.

\section{References}

Barkema H. 1996. Idiomaticity and terminology: A multi-dimensional descriptive model. Studia Linguistica 50.2: 125-160.

Hewings A., Hewings M. 2005. Grammar and context. London, New York.

Lüger H.-H. 1996. Satzwertige Phraseologismen im Text. Elemente eines Mehrebenenmodells. - Beiträge zur Fremdsprachenvermittlung 30: 76-103.

Moon R. 1998. Fixed expressions and idioms in English. Oxford.

Sperber D., Wilson D. 1986. Relevance. Communication and cognition. Oxford.

Szpila G. 2007. Paremiologia a stylistyka. - Stylistyka XVI: 613-632.

Szpila G. 2008a. Paremic verses: proverbial, meanings in Salman Rushdie’s novels. - Journal of Literary Semantics 72: 97-127.

Szpila G. 2008b. Paremic allusions in Salman Rushdie's novels. - Proverbium 25: 379-397.

Szpila G. 2009a. In search of phraseo-sense: Salman Rushdie's idiomatic meanings. - Chrzanowska-Kluczewska E., Szpila G. (eds.) In search of (non)sense. Newcastle upon Tyne: $88-99$.

Szpila G. 2009b. Physical anchoring and referential scope of idioms and proverbs in literature. - Fedulenkova T. (ed.) Cross-linguistic and cross-cultural approaches to phraseology. Arkhangelsk, Aarhus: 171-181.

\section{Salman Rushdie's novels}

$E F=$ Rushdie S. 2008. The enchantress of Florence. London.

$F=$ Rushdie S. 2001. Fury. New York.

$G=$ Rushdie S. 1996. Grimus. London.

GBHF = Rushdie S. 1999. The ground beneath her feet. New York.

$H=$ Rushdie S. 1991. Haroun and the sea of stories. London.

$M C=$ Rushdie S. 1995. Midnight's children. London.

$M L S=$ Rushdie S. 1996. The Moor's last sigh. London.

$S=$ Rushdie S. 1995. Shame. London.

$S C=$ Rushdie S. 2005. Shalimar the clown. London.

$S V=$ Rushdie S. 1998. The satanic verses. London. 